\begin{tabular}{|l|l|l||}
\hline \multicolumn{2}{|c|}{ PublisherInfo } \\
\hline \hline PublisherName & $:$ & BioMed Central \\
\hline \hline PublisherLocation & $:$ & London \\
\hline \hline PublisherImprintName & $:$ & BioMed Central \\
\hline \hline
\end{tabular}

\title{
Memory T cells: division of labour
}

\begin{tabular}{|l|l|l||}
\hline \multicolumn{2}{|c|}{ ArticleInfo } \\
\hline \hline ArticleID & $:$ & 224 \\
\hline \hline ArticleDOI & $:$ & $10.1186 /$ ar-1999-66760 \\
\hline \hline ArticleCitationID & $:$ & 66760 \\
\hline \hline ArticleSequenceNumber & $:$ & 181 \\
\hline \hline ArticleCategory & $:$ & Paper Report \\
\hline \hline ArticleFirstPage & $:$ & 1 \\
\hline \hline ArticleLastPage & $:$ & 3 \\
\hline \hline & & RegistrationDate : 1999-12-6 \\
\hline ArticleHistory & $:$ & OnlineDate \\
\hline \hline ArticleCopyright & $:$ & Current Science Ltd1999-12-6 \\
\hline \hline ArticleGrants & $:$ & \\
\hline \hline ArticleContext & $:$ & 130753311 \\
\hline \hline
\end{tabular}




\section{Keywords}

CCR7, $\mathrm{CD} 4^{+}$cell, $\mathrm{CD} 8^{+}$cell, cell mediated immunity, $\mathrm{T}$ cell

\section{Context}

A rapid and vigorous response is characteristic of immunological memory of a previously encountered pathogen. Vaccination is based on this memory, but surprisingly little is known of how $\mathrm{T}$ and $B$ cells mediate it. In particular it has been difficult to distinguish naive, memory and effector $T$ cells. Understanding exactly how the facets of immunity are normally controlled will shed light on the pathology of immunity when it is out of control. To explore the idea that chemokine receptor CCR7 may distinguish subsets of memory $\mathrm{T}$ cells.

\section{Significant findings}

Analysis of CD45 and CCR7 expression distinguished three subsets of $\mathrm{CD} 4^{+}$cells (naive $\mathrm{T}$ cells and two memory $\mathrm{T}$ cell subsets) and four subsets of $\mathrm{CD} 8^{+}$cells. $\mathrm{CCR} 7^{+}$memory cells appear to share migratory routes with naive $\mathrm{T}$ cells.

Activation requirement studies showed the CCR7 $7^{-}$cells to be the more responsive of the two $\mathrm{CD} 4^{+}$ memory subsets, although both were more sensitive than naive cells. Coculture experiments demonstrated that $\mathrm{CCR} 7^{+}$memory cells proliferate more readily than naive cells upon TCR stimulation and are potent activators of IL-12 production by DCs.

Stimulation of naive $\mathrm{CD} 4^{+}$cells led to loss of CCR7 and this correlated with acquisition of the ability to produce IL-4 and IFN-a. Both $\mathrm{CD} 4^{+}$memory subsets proliferated in response to stimulation with tetanus toxoid but only the $\mathrm{CCR}^{-}$subset produced IFN-a.

\section{Comments}


This basic immunological research is relevant to vaccine design, xenotransplantation and immunomodulatory therapy in T-cell-mediated autoimmune diseases. A greater understanding of the function and homing patterns of different $\mathrm{T}$ cell memory subsets may enable the selective depletion of pathological T cell subsets, or receptor blockade to prevent their access to particular tissues.

\section{Methods}

Flow cytometry was used to investigate subsets of memory $\mathrm{T}$ cells to determine whether differential expression of surface markers might correlate with distinct homing and effector mechanisms. $\mathrm{CD} 4{ }^{+}$and $\mathrm{CD}^{+}$cells were examined for expression of CD45RA and CD45RO (markers for human naive and memory T cells respectively) and the lymph node "entry code" molecules CCR7 and CD62L. The authors also investigated expression of chemokine receptors and adhesion molecules, comparing naive $\mathrm{T}$ cells with memory T cell subsets determined by CCR7 expression. Next, they explored whether cell stimulation led to differing patterns of cytokine and CD40L expression. Activation requirements were studied using anti-CD3 in the presence and absence of costimulation. Coculture of $\mathrm{T}$ cells with dendritic cells (DCs) following stimulation by bacterial superantigen allowed quantitation of the DCs' IL-12 production.

Having demonstrated two subsets of circulating memory T cells distinguishable by CCR7, the group investigated the subsets' 'memory' for antigen. Using $\mathrm{T}$ cells from individuals vaccinated against tetanus toxoid and hepatitis B surface antigen, they compared the memory $\mathrm{T}$ cell subsets' ability to proliferate when rechallenged. To address the relationship of naive and memory subset $\mathrm{T}$ cells to one another, polyclonal stimulation of naive cells was performed, followed by assays for CD45RA, CCR7, IL-2, IL-4, IL-5 and IFN-?. Finally, CCR ${ }^{+}$memory T cells were investigated 10 days after stimulation, for markers suggesting differentiation. Telomere length analysis was also performed, as length decreases with the number of divisions undergone by a cell line.

\section{References}

1. Sallusto F, Lenig D, Forster R, Lipp M, Lanzavecchia A: Two subsets of T lymphocytes with distinct homing potentials and effector functions. Nature. 1999, 401: 708-712.

This PDF file was created after publication. 